Original articles

J. Perinat. Med.

13 (1985) 155

\title{
Elective induction of labor: a prospective clinical study,I: Obstetric and neonatal effects
}

\author{
M. E. Vierhout, J. J. Out*, H. C. S. Wallenburg
}

Departments of Obstetrics and Gynecology, and Medical Psychology*, Erasmus University Medical School, Rotterdam, the Netherlands

\section{Introduction}

Elective induction of labor should be defined as induction of labor in the absence of a medicalobstetric indication for termination of pregnancy. There is considerable disagreement with regard to the advantages and disadvantages of this obstetric procedure $[2,4,8,9,17,20,22]$. Those who are in favor emphasize the safety of the procedure [10] because labor can be scheduled during the daytime when it is assumed that optimal care can be given $[10,16]$. Fetal monitoring can be used from the beginning of labor. The potential to prevent term fetal death of unknown cause has also been put forward as an argument in favor of elective induction of labor $[1,11]$.

Reported disadvantages include the feeling that it is an unnatural procedure [2], the danger of an induced premature delivery [7], the risks of overstimulation of uterine activity by oxytocin [13], prolaps of the umbilical cord and intrauterine infection caused by artificial rupture of membranes [21], and the discomfort of immobilization for the patient [15].

A critical assessment of such potential advantages and disadvantages appears to be hardly possible on the basis of the available literature because of the use of different and often illdefined definitions of elective induction. Furthermore, in the majority of these retrospective studies, criteria for selection of patient groups

\section{Curriculum vitae}

MARK E. VIERHout was born in 1948 in Djakarta (Indonesia). He studied medicine at the University of Groningen. From 1976 to 1978 he worked in the St. Elisabeth Hospital in Curacao, Dutch Antilles. From 1978 to 1983 he did his residency in Obstetrics and Gynecology at the University Hospital Dijkzigt,

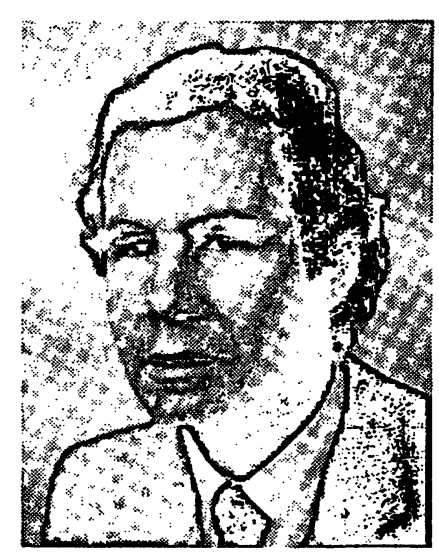
Rotterdam. In 1983 he received a Ph. D. from the Erasmus University, Rotterdam with a thesis on elective induction of labor. At present he is employed as an obstetrician and gynecologist at the Medical Department of Brunei Shell Petroleum Company Ltd. in Brunei, N. W. Borneo.

are not presented. Such criteria are only given in one prospective study in which the results of 43 elective inductions are discussed [19].

The present prospective study was performed to determine the differences between elective induction and spontaneous labor with regard to obstetric and neonatal outcome, as well as to development of the infants in the first year.

\section{Patients and methods}

All women who took part in this study were delivered in the Department of Obstetrics, Uni- 
versity Hospital - Dijkzigt, Rotterdam, between May 1980 and September 1981. Women in whom labor was electively induced constitute the "induction group". The obstetric and neonatal outcome in this group was compared to the outcome in a reference group of women in whom labor started spontaneously and who were selected in the same period of time.

\subsection{Criteria for selection}

The study group was selected from healthy women receiving antenatal care in our clinic starting in the first trimester. Gestational age was substantiated by ultrasound examination between 18 and 20 weeks' amenorrhea and only singleton pregnancies were included. Women with a complicated obstetric history or with complications in the present pregnancy were excluded (Tab. I). Women who met the criteria to take part in the study at 36 weeks' gestational age and who had a fetus with a cephalic presentation without cephalopelvic dysproportion were given written and oral information about the procedure of elective induction of labor. They were at all times allowed a free choice of elective induction or spontaneous labor. A set of "matched controls" was used as a reference group. Each woman who was electively induced was matched with a healthy woman with an uncom-

Tab. I. Medical reasons for exclusion of patients.

\section{Obstetric History}

1. Cesarean section

2. Perinatal death

3. Vacuum or forceps delivery

\section{Present Pregnancy}

1. Diastolic blood pressure $>90 \mathrm{mmHg}$

2. Gestational or type I diabetes mellitus

3. Proteinuria

4. Vaginal bleeding during the last trimester

5. Premature rupture of membranes

6. Polyhydramnios

7. Sever anemia (hemoglobin concentration $<6 \mathrm{mmol} / \mathrm{l})$

8. Rhesus iso-immunization

9. Recurring urinary tract infections

10. Any serious illness occurring during pregnancy plicated pregnancy who went into spontaneous labor. Three criteria were used for matching: age $(<22,23-27,>28$ years), parity (nulliparous or parous) and cultural nationality (Dutch or non-Dutch). The reference group was also selected around the 36th week of pregnancy. There were 28 women in the reference group in whom complications occurred between the 36 th week and delivery. For this reason the induction group consists of 184 women as compared with 156 women in the reference group.

\subsection{The induction group}

In women who opted for elective induction of labor, cervical ripeness was assessed in the 38th week of pregnancy with the use of the BuRNHILL score [3]. When the cervix was considered "ripe" - a score greater than four - the date for induction of labor was set. At the time of induction the membranes were artificially ruptured, and a fluidfilled open-tip catheter was introduced transcervically into the amniotic cavity for the recording of uterine activity. An electrode was attached to the fetal scalp for fetal heart rate monitoring. Uterine contractions were induced with intravenous infusion of an incremental dose of oxytocin starting with $2 \mathrm{mU} / \mathrm{min}$, until uterine activity of $150-200$ Montevideo units was obtained.

\subsection{The reference group}

In this group the beginning of labor was defined as the moment at which regular pains started with an interval of four to five minutes, or as the moment of spontaneous rupture of the membranes. Internal fetal monitoring was only used when fetal distress was suspected $(n=29)$ or when it appeared to be necessary to augment uterine activity $(\mathrm{n}=15)$.

\subsection{Both groups}

If necessary, a standard dose of $75 \mathrm{mg}$ of pethidine-HCL I. M. was given for pain relief. Immediately after birth the infant was placed on 
the mother's abdomen and the umbilical cord was ligated. APGAR scores were determined at one and five minutes. The acid-base status was determined from umbilical cord arterial blood obtained immediately after delivery. On the third post-partum day the bilirubin concentration in serum was determined in all newborns which were still in the hospital. Neurological screening according to PRECHTL [14] was performed in a random sample $(n=125)$. The development of the infants was followed during one year, using a "Psychomotor Development Scheme 0-15 months" [16].

All data were analyzed with a P. D. P. 11/70 minicomputer using the Statistical Package for
Social Sciences System. Statistical analysis of the differences between the induction and reference groups was performed with STUDENT's ttest and with the $X^{2}$-test, where appropriate. The SPEARMAN test was used to assess correlations between variables. A probability of $\mathrm{p}<0.05$ was chosen to represent statistical significance.

\section{Results}

The composition of both groups is summarized in Tab. II. A significant difference in the duration of amenorrhea was found between the induction and reference group. Both nullipa-

Tab. II. Age, parity and nationality of the women in the induction group $(n=184)$ and in the reference group $(\mathrm{n}=156)$.

\begin{tabular}{llllllll}
\hline & $\begin{array}{l}\text { Age } \\
<22\end{array}$ & $23-27$ & $\geq 28$ & $\begin{array}{l}\text { Parity } \\
\text { Nulliparous }\end{array}$ & Parous & $\begin{array}{l}\text { Nationality } \\
\text { Dutch }\end{array}$ & non-Dutch \\
\hline Induction & 24 & 87 & 73 & 60 & 124 & 160 & 24 \\
group & $(13.0 \%)$ & $(47.3 \%)$ & $(39.7 \%)$ & $(32.6 \%)$ & $(67.4 \%)$ & $(87.0 \%)$ & $(13.0 \%)$ \\
Reference & 15 & 69 & 72 & 41 & 115 & 139 & 17 \\
group & $(9.6 \%)$ & $(44.2 \%)$ & $(46.2 \%)$ & $(26.3 \%)$ & $(73.7 \%)$ & $(89.1 \%)$ & $(10.9 \%)$ \\
\hline
\end{tabular}

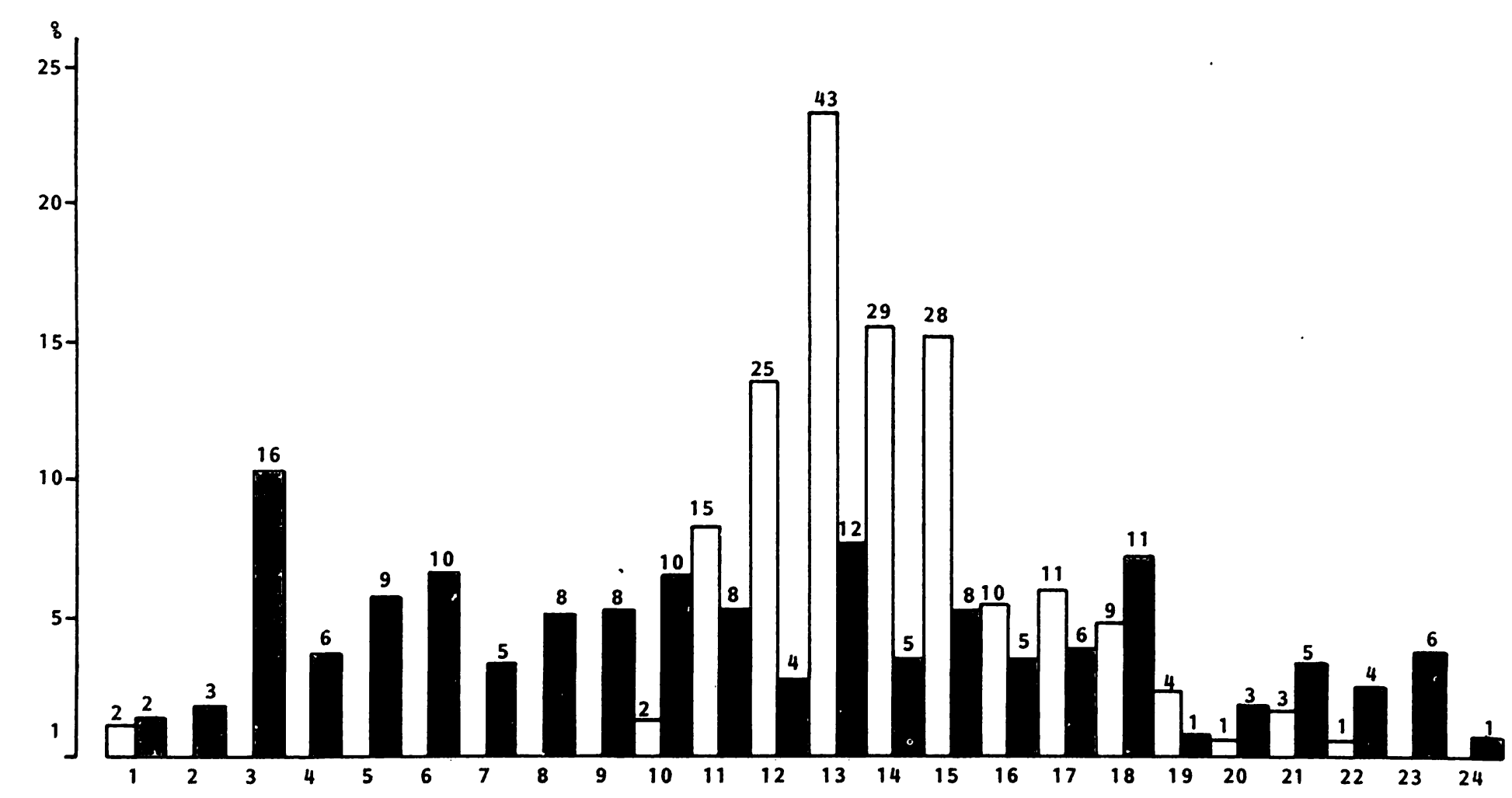

Fig. 1. Distribution of the times of delivery (hours) in the induction group ( $\square$ ) and in the reference group ( $\square$ ). 
rous and parous women in the induction group delivered three days earlier than those in the reference group. Nearly $95 \%$ of the deliveries in the induction group took place during daytime (8-18 hours) as compared to only $45 \%$ in the reference group (Fig. 1). The median value of the cervical ripeness score in the induction group was 5.5 for nulliparous and 6.0 for parous women. No significant correlation could be demonstrated between the cervix scores and the duration of the first stage of labor. The first stage of labor in the induction group was significantly shorter than that in the reference group (Tab. III).

No differences in the duration of the second stage of labor were found between the groups. Meconium stained amniotic fluid occurred significantly less frequently in the induction group than in the reference group $(2.7 \%$ vs. $8.3 \%)$.

Medication for pain relief was significantly less frequently given in the reference group (24.4\%) than in the induction group $(49.5 \%)$. Three women in the induction' group and one in the reference group were delivered by cesarean section. In one patient the induction of labor could be held responsible for the necessity to perform a cesarean section. In this patient, a partial abruptio placentae occurred immediately following insertion of the intrauterine pressure catheter. In the other two patients no relationship was apparent between the induction of labor and the reason for cesarean section. In the induction group there was a significantly higher percentage of vacuum and forceps deliveries $(11.9 \%)$ than in the reference group $(4.5 \%)$. Suspicion of fetal distress was the reason to terminate delivery in nine cases in the induction group compared to two cases in the reference group. Lack of progression in the second stage of labor formed the indication to perform a vacuum or forceps extraction in 13 women of the induction group as compared to five women of the reference group. The amount of blood loss during labor and post partum did not differ significantly between the two groups.

Tab. III. Duration of the first and second stage of labor in minutes (mean \pm S. D.) in the various groups.

\begin{tabular}{lcccc}
\hline & $\mathrm{n}$ & First stage & $\mathrm{n}$ & Second stage \\
\hline Induction group nulliparous & $58^{*}$ & $349 \pm 138$ & 58 & $37 \pm 18$ \\
Reference group nulliparous & $40^{*}$ & $482 \pm 204$ & 40 & $38 \pm 22$ \\
Induction group parous & $123^{*}$ & $268 \pm 121$ & 123 & $15 \pm 11$ \\
Reference group parous & 115 & $340 \pm 168$ & 115 & $\cdot 12 \pm 8$ \\
\hline
\end{tabular}

* Women who underwent cesarean section are omitted.

Tab. IV. Birthweights (median and range) and the APGAR scores and low umbilical arterial $\mathrm{pH}$ values in the various groups.

$\begin{array}{lll}\text { Birth weight } & \text { Apgar-scores } & \text { Umbilical arterial } \\ \text { (g) } & <7 & \mathrm{pH}<7.15 \\ & \mathrm{n} & \mathrm{n}\end{array}$

\begin{tabular}{lclccc}
\hline $\begin{array}{l}\text { Induction group } \\
\text { nulliparous }\end{array}$ & $58^{*}$ & $\begin{array}{l}3400 \\
(2260-4410)\end{array}$ & 3 & 10 & $\ldots$ \\
$\begin{array}{l}\text { Reference group } \\
\text { nulliparous }\end{array}$ & $40^{*}$ & $\begin{array}{l}3375 \\
(2573-4370)\end{array}$ & 2 & 5 & \\
$\begin{array}{l}\text { Induction group } \\
\text { parous }\end{array}$ & $123^{*}$ & 3468 & 3 & 6 & \\
$\begin{array}{l}\text { Reference group } \\
\text { parous }\end{array}$ & 115 & $\begin{array}{l}(2530-4410) \\
(2786-4540)\end{array}$ & 2 & 5 \\
\hline
\end{tabular}

* Women who underwent cesarean section are omitted. 
Tab. V. Serum bilirubin concentrations (mean \pm S.D.) in the newborns on the third day and the number of newborns treated with phototherapy.

Bilirubin concentration $(\mu \mathrm{mol} / \mathrm{l})$

\section{Infants with a}

bilirubin concentration $>200 \mu \mathrm{mol} / 1$

n
Infants receiving phototherapy

$\mathrm{n}$
Induction group $(\mathrm{n}=184)$

Reference group $(n=156)$
$130 \pm 56.2$

$121 \pm 51.8$
18

10
9

4
With regard to the newborns, no significant differences between birthweights, APGAR scores and umbilical arterial blood gas values in the two groups were found (Tab. IV). There was also no significant difference between the neonatal bilirubin values in the two groups (Tab. V).

The results of the neurological screening in 67 infants of the induction group were not different from those in the 58 infants of the reference group. In the induction group nine infants $(13.4 \%)$ were considered "suspect" as compared to seven infants $(12.1 \%)$ in the reference group.

The follow-up study of the infants during their first year of life did not reveal any differences between the groups. In both groups three children were suspected to have slightly impaired psychomotor development, but no relationship with the mode of labor and delivery was apparent.

\section{Discussion}

The supposed greater safety of elective induction as compared with spontaneous labor for both mother and infant could not be confirmed in our study. Almost all electively induced women were delivered during daytime. However, there is no reason to suppose that in our hospital setting this fact had any influence on the quality of care. In both groups the condition of the newborns was good. A less frequent occurrence of meconium stained amniotic fluid in electively induced labor has also been reported in other studies $[5,18]$. The explanation of this finding is not clear. Iatrogenic prematurity did not occur in our study. Ultrasound examination to confirm the duration of pregnancy can be considered of paramount importance to prevent this complication. The time with which the duration of pregnancy was reduced in women with electively induced labor as compared to women with spontaneous labor was only three days. This can be explained by the fact that induction was not started until the cervix was considered to be "ripe". The finding of a higher percentage of vacuum and forceps deliveries in the induction group could, in retrospect, not be explained by a higher frequency of fetal distress or a prolonged second stage of labor. The fact that fetal heart rate was continuously monitored in all women in the elective induction group could be an important contributing factor. It may also be possible that the obstetrician feels more responsible for a good result when labor is electively induced: "Having started the woman's labor electively and closely following it to full dilatation with fetal monitoring, the obstetrician may well feel that he can ensure successful delivery by intervening in the second stage as well [22]". The results of the neurological examination of the newborns and of the follow-up study did not reveal any differences between the infants in the two groups, which is in agreement with the results of other studies $[6,12]$.

It is concluded that no somatic obstetric or neonatologic arguments against or in favor of the procedure of elective induction of labor can be derived from the results of this study. The decision to electively induce labor must be based on other than somatic considerations. 


\section{Summary}

Elective induction of labor is still a controversial obstetric procedure. The safety of the procedure and the possibility to program labor during daytime is an often heard argument in favor of it. Also the possibility to prevent term intrauterine fetal death of unknown cause and the possibility to apply fetal monitoring from the beginning of labor are put forward as arguments in favor of elective induction of labor. Feelings of unnaturalness and the dangers of prematurely induced delivery are the most often heard arguments against it. We performed a prospective study to determine the differences between elective induction of labor and spontaneous labor. During 17 consecutive months a group of 184 elective inductions was studied in the Department of Obstetrics, University Hospital Dijkzigt, Rotterdam. Only healthy women with an uncomplicated pregnancy were included in the study group and all women were allowed a free choice of elective induction or spontaneous labor. The reference group was composed by a system of "matched controls". For induction of labor a standard technique including artificial rupture of the membranes and constant intrauterine fetal monitoring was used. Oxytocin was administered intravenously in an incremental dose. After delivery the acid-base status of the newborns was determined, and part of the newborns were subjected to a neurological screening according to PRECHTL. The developments of the infants was followed during one

Keywords: Induction of labor, elective, oxytocin.

\section{Zusammenfassung}

Programmierte Geburt - eine prospektive klinische Studie, I.: geburtshilfliche und neonatologische Aspekte

Die programmierte Geburt ist in der Geburtshilfe weiterhin ein kontroverses Thema. Weit verbreitete Argumente für die Einleitung sind die Sicherheit der Methode und die Möglichkeit, die Geburt während eines normalen klinischen Tagesablaufes zu programmieren. Auch die Möglichkeiten, einen intrauterinen Tod unbekannter Ursache am Termin zu vermeiden sowie ein fetales Monitoring von Geburtsbeginn an durchzuführen, sprechen für aktive, einleitende Maßnahmen. Dagegen sprechen Argumente, die auf die ,Unnatürlichkeit' der Methode und die Gefahr der Unreife bei induzierten Geburtsabläufen hinweisen. Wir führten eine prospektive Studie durch, um die Unterschiede zwischen programmierten und spontanen Geburten zu erfassen. In der Geburtsabteilung des Universitätskrankenhauses Dijkzigt, Rotterdam, wurde innerhalb eines Zeitraums von 17 Monaten eine Gruppe von 184 Frauen mit programmierter Geburt untersucht. Die Gruppe umfaßte nur gesunde Frauen nach unkomplizierter Schwangerschaft, denen freigestellt war, ob sie sich für eine Einleitung oder eine Spontangeburt entscheiden. Die Referenzgruppe war year using a "psychomotor development scheme $0-15$ months".

The duration of pregnancy appeared to be three days shorter in the induction group than in the reference group. Also the first stage of labor was significantly shorter in the induction group as compared to the reference group. It appeared possible to program labor almost exclusively during daytime. Meconium stained amniotic fluid occurred significantly less frequently in the induction group than in the reference group. In one patient the induction of labor could be held responsible for the necessity to perform a cesarean section. There was a significantly higher percentage of vacuum and forceps deliveries in the induction group $(11.9 \%)$ than in the reference group (4.5\%). No difference between birthweights, APGAR scores and umbilical arterial blood gas values in the two groups were found. Neither the neurological screening nor the follow-up study of the infants revealed any differences between the two groups. We were not able to confirm the often postulated greater safety of the procedure. A greater number of vacuum and forceps deliveries in the induction group could, in retrospect, not be explained by a higher frequency of fetal distress in this group. This study did not provide sound arguments against or in favor of the procedure of elective induction of labor.

It is concluded that the decision to electively induce labor must be based on other than somatic considerations.

nach dem System der ,matched controls' zusammengestellt. Die Geburtseinleitung erfolgte nach standardisierter Technik mit Blasenpunktion und intravenöser Oxytocininfusion in ansteigender Dosierung bei konstantem intrauterinen, fetalen Monitoring. Post partum wurde der Säure-Basen-Status der Neugeborenen untersucht sowie ein Teil der Kinder einem neurologischen Screening nach PRECHTL unterzogen. Während des ersten Lebensjahres wurde die kindliche Entwicklung unter Anwendung eines ,psychomotorischen Entwicklungsschemas 0-15 Monate' verfolgt.

Die Dauer der Schwangerschaft war in der Einleitungsgruppe 3 Tage kürzer als in der Kontrollgruppe. Auch die Eröffnungsperiode war in der Einleitungsgruppe signifikant verkürzt gegenüber der Kontrollgruppe. Wie es scheint, werden Geburten fast ausschließlich während des Tages programmiert. Mekoniumhaltiges Fruchtwasser trat in der Einleitungsgruppe signifikant weniger häufig auf als in der Kontrollgruppe. Bei einer Patientin war die Geburtseinleitung wahrscheinlich der Grund für die Notwendigkeit einer Sectio. Der Anteil an Vakuumextraktionen und Zangenentbindungen war in der Einleitungsgruppe deutlich höher als in der Kontroll- 
gruppe $(11,9 \%$ vs. $4,5 \%)$. Bezüglich des Geburtsgewichts, des APGAR-Scores und der Blutgaswerte in der Nabelarterie unterschieden sich die Gruppen nicht. Ebenso ergaben weder das neurologische Screening noch die Nachuntersuchungen Hinweise für Unterschiede zwischen den Gruppen.

Wir können die oft postulierte Aussage, daß eine programmierte Geburt sicherer ist, nicht bestätigen. Retro-

Schlüsselwörter: Oxytocin, programmierte Geburt. spektiv kann die erhöhte Anzahl von Vakuumextraktionen und Zangenentbindungen nicht durch eine stärkere Frequenz von fetalem Distress in dieser Gruppe erklärt werden. Diese Studie liefert keine schlagkräftigen Argumente für oder gegen eine programmierte Geburt.

Wir meinen, daß die Entscheidung für eine programmierte Geburt nicht auf der Basis rein medizinischer Überlegungen getroffen werden kann.

\section{Résumé}

Déclenchement électif du travail: étude clinique prospective, I: effets obstétricaux et néonataux

Le déclenchement du travail est encore une procédure obstétricale contreversée. La sécurité du procédé et la possibilité de programmer le travail pendant la journée, sont des arguments souvent entendus en sa faveur. La possibilité d'éviter les morts fœtales in utéro à terme de cause inconnue et la possibilité de mettre en œuvre le monitoring fœtal dès le début du travail sont également mis en avant comme arguments en faveur du déclenchement du travail. Les arguments les plus souvent entendus contre le déclenchement sont le sentiment d'aller contre la nature et le danger d'induire un accouchement prématuré. Nous avons réalisé une étude prospective afin de déterminer les différences entre le déclenchement du travail et le travail spontané. Pendent 17 mois consécutifs, un groupe de 184 déclenchements a été étudié dans le département d'Obstétrique, à l'hôpital universitaire Dijkzigt de Rotterdam. On n'a inclu dans le groupe étudié que des femmes en bonne santé avec une grossesse dépourvue de complication et toutes les femmes ont eu le libre choix d'un déclenchement du travail ou d'un travail spontané. Le groupe de référence a été établi par un système «d'appariement controle». Pour le déclenchement du travail, on a utilisé une technique standard comprenant la rupture artificielle des membranes et un monitoring fœtal intra-utérin permanent. L'ocytocique a été utilisé par voie intraveineuse à doses progressives. Après l'accouchement, on a déterminé l'équilibre acidobasique des nouveaux-nés et une partie des nouveauxnés a été soumise à un bilan neurologique de PreChTL. On a suivi le développement des enfants pendant un an

en se servant d'un schéma de développement psychomoteur de 0 à 15 mois.

La durée de la grossesse est plus courte de trois jours dans le groupe déclenché que dans le groupe de référence. Egalement, la première partie du travail est significativement plus courte dans le groupe déclenché en comparaison avec le groupe de référence. Il apparaît possible de programmer le travail presque exclusivement pendant la journée. L'apparition de liquide amniotique teinté de méconium est significativement moins fréquente dans le groupe déclenché que dans le groupe de référence. Chez une patiente, le déclenchement du travail peut être tenu comme responsable de la nécessité de réaliser une césarienne. Il y a un pourcentage significativement plus élevé de ventouse et de forceps dans le groupe déclenché $(11,9 \%)$ que dans le groupe de référence $(4,5 \%)$. On n'a pas trouvé de différence entre les poids de naissance, les scores d'APGAR et les valeurs des gaz sanguins dans l'artère ombilicale dans les deux groupes. Ni le bilan neurologique, ni le suivi des enfants n'ont révélés de différence entre les deux groupes.

Nous ne sommes pas capables de confirmer la plus grande sécurité souvent postulée de cette procédure. Le nombre plus élevé de ventouse et de forceps dans le groupe déclenché, ne peut rétrospectivement être expliqué par une fréquence plus élevée de souffrances fotales dans ce groupe. Cette étude ne fournit pas d'argument pour ou contre le déclenchement du travail. Les auteurs concluent que la décision du déclenchement du travail doit être fondée sur des considérations autres que médicales.

Mots-clés: Declenchement du travail, électif, ocytocine.

\section{Bibliography}

[1] BAIRD, D.: Induction of labour. Br. Med. J. 1 (1976) 896

[2] Cartwright, A.: The dignity of labour? Tavistock Publications, London 1979

[3] Burnhill, M. S., J. Danezis, J. Cohen: Uterine contractility during labor studied by intra-amniotic fluid pressure recordings. Am. J. Obstet. Gynecol. 83 (1962) 56 
[4] Chard, T., M. Richards (eds.): Benefits and hazards of the new obstetrics. Spastics Intern. Med. Publications, London

[5] Cole, R. A., P. W. Howie, M. C. MacNaughton: Elective induction of labour. The Lancet 1 (1975) 767

[6] Friedman, E. A., M. R. Sachtleben, A. K. WALLACE: Infant outcome following labor induction. Am. J. Obstet. Gynecol. 133 (1979) 718

[7] HaCK, M., A. A. - Fanaroff, M. H. Klaus: Neonatal distress following elective delivery. A preventable disease? Am. J. Obstet. Gynecol. 126 (1976) 43

[8] L'Accouchement Programmé. Quatrième rapport. J. Gynecol. Obstet. (Paris) Biol. Reprod. 11 (1982) 105

[9] Lancet, The. Editorial: A time to be born. Lancet 2 (1974) 1183

[10] Martius, G.: Terminierung der Geburt als präventive Massnahme. Med. Klin. 20 (1979) 745

[11] McNay, B. M., G. W. McIlwaine, P. W. Howie, M. C. MacNaughton: Perinatal deaths: analysis by clinical cause to assess value of induction of labour. Br. Med. J. 1 (1977) 347

[12] Niswander, K. R., R. J. Patterson: Development status of children delivered through elective induction of labor. Obstet. Gynecol. 27 (1963) 15

[13] Petrie, R. H.: The pharmacology and use of oxytocin. Clin. Perinatol. 8 (1981) 35

[14] PreChtL, H.: The neurological examination of the full term newborn infant. Clin. in Developmental Medicine. 63. Spastic Intern. Med. Publications, London 1977
[15] Roberts, B., C. Mendéz-Bauer: A perspective of maternal position during labor. J. Perinat. Med. 8 (1980) 255

[16] SCHLESINGER-Was, E. A.: Ontwikkelingsonderzoek van zuigelingen en kleuters op het consultatiebureau. Academic Thesis, Leiden 1981

[17] Thiery, M.: Het inleiden van de baring. De Nederlandse Bibliotheek der Geneeskunde. Deel 148. Stafleu. Alphen aan den Rijn 1981

[18] TIlCh, G., F. Unger, J. STARK: Einfluss einer individuellen Programmierung der Geburt auf verschiedene perinatologische Parameter. Zentralbl. Gynaekol. 101 (1979) 191

[19] Tylleskar, J., O. Finnstrom, I. Leijon, S. HedenSKOG, G. RYDEN: Spontaneous labour and elective induction - A prospective randomized trial. Acta Obstet. Gynecol. Scand. 58 (1979) 513

[20] VIERhout, M. E., J. J. OUT: De electieve inleiding van de baring. Academic Thesis, Rotterdam 1983

[21] VISSER, H. G. A.: De inleiding van de baring. Academic Thesis, Groningen 1978

[22] Yudkin, P., A. M. Frumar, A. B. M. Anderson, A. C. TURNBULL: A retrospective study of induction of labour. Br. J. Obstet. Gynaecol. 86 (1979) 257

Received August 13, 1984. Accepted October 26, 1984.

Prof. Dr. H. C. S. Wallenburg

Department of Obstetrics and Gynecology

Erasmus University Medical School, Ee 2283

P. O. Box 1738

3000 DR Rotterdam

The Netherlands 